ОСОБЛИВОСТІ ПОДОЛАННЯ ЕКЗАМЕНАЦІЙНОГО СТРЕСУ СТУДЕНТАМИ-ПЕРШОКУРСНИКАМИ З РІЗНИМ РІВНЕМ ТРИВОЖНОСТІ

\title{
THE PECULIARITIES OF OVERCOMING EXAMINATION STRESS BY FIRST-YEAR STUDENTS WITH DIFFERENT LEVELS OF ANXIETY
}

Стаття присвячена розв'язанню проблеми подолання екзаменаційного стресу студентами. Автором проаналізовано сутність ситуації іспиту як стресогенної та виокремлено їі ознаки, що зумовлюють як позитивні, так і негативні впливи на психоемоційний стан особистості. Вказано на роль особистісних ресурсів у подоланні екзаменаційного стресу.

Представлено результати експериментального дослідження впливу емоційно-вольових властивостей особистості на способи подолання екзаменаційного стресу, встановлено взаємозв'язок тривожності як особистісної властивості та екзаменаційної тривожності як специфрічного психічного стану, що виникає в ситуації іспиту.

Встановлено зумовленість рівня екзаме наційної тривожності емоційно-вольовими властивостями особистості та виокремлено типологію студентів з різними рівнями тривожності. Провідними особистісними рисами респондентів з низьким рівнем екзаменаційної тривожності є впевненість у собі і своїх здібностях, яка інколи переходить у самовпевненість, врівноваженість, незворушність, розсудливість, нечутли вість до загроз, що поєднується 3 апатією, в'ялістю та низькою мотивацією, лінню. У студентів з високим рівнем екзаменаційної тривожності зафіксовано такі особистісні риси, як невпевненість у собі та своїх силах, схильність до поганого настрою, очікування неуспіху, песимізм, що переплітається з наполегливістю, відповідальністю, почуттям обов'язку, вимогливістю до себе. Студенти, які виявили середній рівень екзаменаційної тривожності разом з помірною вимогливістю до себе, відповідальністю, прагматичністю та незворушливістю, виявляють більшу агресивність та брак або слабку мотивацію, що призводить до невисоких результатів навчання та діяльності.

Виявлено значущий зв'язок між емочійновольовими властивості особистості та особливостями сприймання екзаменаційноі ситуації як загрозливої або стимулюючої; а також значущий зв'язок між рівнем тривожності як особистісної властивості і рівнем екзаменаційної тривожності та самооцінкою студентами психоемоційного стану за критеріями психічної активації, напруженості, емоційного тонусу, інтересу та комфортності.

Виявлено статистично значущі розбіжності за частотою вибору способів подолання екзаменаційного стресу респондентами з різними рівнями тривожності. $у$ студентів-першокурсників загалом склалася система сталих когнітивних, поведінкових довільних способів подолання екзаменаційного стресу. Так, студенти з високим рівнем тривожності оцінюють ситуацію іспиту як загрозливу, $і$ че змушує їх вдаватися до широкого діапазону як конструктивних, але й деструктивних способів подолання екзаменаційного хвилювання, тоді як студенти 3 низьким рівнем тривожності уникають деструктивних способів подолання екзаменаційного стресу.

Отримані результати засвідчують, що студенти-першокурсники потребують орормування релевантних стресовим ситуаціям та емоційно-вольовим властивостям особистості способів подолання екзаменаційного стресу задля підвищення ефективності діяльності у ситуаціях випробовування та збереження психологічного здоров'я.

Ключові слова: стрес, екзаменаційний стрес, емоційно-вольові якості особистості, способи подолання стресу, тривожність.

The article is devoted to solving the problem of overcoming examination stress by students. The author has analyzed the essence of the examination situation as stressful and has highlighted its features that cause positive as well as negative effects on the psycho-emotional state of personality. The role of personal resources in overcoming examination stress is pointed out.

The results of the experimental study of the influence of emotional-volitional personality traits on the ways of overcoming examination stress are presented; the relationship between anxiety as a personality trait and examination anxiety as a specific mental state that arises in the examination situation is established.

The dependence of the level of examination anxiety on the emotional-volitional personality traits is established and the typology of students with different levels of anxiety is singled out. The leading personality trait of respondents with low levels of examination anxiety is confidence, which sometimes transforms into self-confidence, poise, calmness, prudence, sensibility, insensitivity to threats, combined with apathy, lethargy and low motivation, laziness. Students with high level of examination anxiety demonstrate such personal traits as uncertainty, a tendency to be in a bad mood, expectations of failure, pessimism, which is combined with persistence, responsibility, a sense of duty, self-demand. Students who show an average level of examination anxiety demonstrate moderate self-demand, responsibility, pragmatism and calmness as well as more aggression and lack or weak motivation, which leads to low learning and activity outcomes.

There is a significant relationship between the emotional-volitional personality traits and the peculiarities of perception of the examination situation as threatening or stimulating; as well as there is a significant relationship between the level of anxiety as a personality trait and the level of examination anxiety and students' self-assessment of psycho-emotional state in terms of mental activation, tension, emotional tone, interest and comfort. The statistically significant differences in the frequency of choice of ways to overcome the examination stress by respondents with different levels of anxiety have been found out. The firstyear students generally have a system of stable cognitive, behavioral arbitrary ways of overcoming examination stress. Thus, students with a high level of anxiety assess the exam situation as threatening and this forces them to resort to a wide range of both constructive and destructive ways of overcoming examination excitement,
Кам'янець-Подільський національний університет імені Івана Огієнка 
while students with low anxiety avoid destructive ways of overcoming examination stress.

The obtained results prove that the first-year students need to form relevant to stressful situations and emotional-volitional personality traits ways of overcoming examination stress in order to increase the effectiveness of activity in situations of testing and maintaining mental health

Key words: stress, examination stress, personality's emotional-volitional qualities, ways to overcome stress, anxiety.
Постановка проблеми. Психологічне здоров'я студентів значною мірою визначається особливостями їх емоційної сфери та тими психічними станами, які виникають в процесі здійснення навчально-професійної діяльності. Існування так званого стресогенного екзаменаційного ефекту, який виявляється в стійкому і значному негативному впливі ситуації екзамену на функціональний стан фізіологічних систем і психіки студента, призводить до появи дезадаптивних форм самопочуття та способів поведінки. Пом'якшення негативних наслідків стресових ситуацій можливе за умови довільної регуляції власного психоемоційного стану особистістю. Розуміння особливостей впливу емоційно-вольових властивостей особистості на вибір способів поведінки у стресовій ситуації сприятиме створенню прийомів цілеспрямованого формування ресурсів подолання стресу, зокрема стресу екзаменаційного.

Аналіз останніх досліджень та публікацій. Lasarus R.S. i Launier R. визначають психологічний стрес як реакцію на особливості взаємодії людини з навколишнім світом [9], що $€$ продуктом когнітивних процесів. Тобто фактично стрес виникатиме за умови незадовільного результату аналізу та оцінки ситуації, яка склалася, наслідків, ресурсів, які $€$ у людини, наявних стратегій та способів управління поведінкою та діяльністю в цих умовах. Не кожна нова ситуація розглядається індивідом як емоціогенна. Для набуття нею ознак такої вона повинна оцінюватися індивідом як суб'єктивно значуща [2] або така, яка, за оцінками індивіда, несе загрозу, якої неможливо уникнути [9]. Такі ситуації викликають емоційне реагування. Певний тип реагування студента в ситуації екзамену залежить від низки чинників, перш за все індивідуально-типологічних та індивідуально-психологічних особливостей студента [6; 8]. Водночас поведінка особистості в ситуації екзаменаційного стресу передбачає наявність у першокурсника ресурсів для подолання складної життєвої ситуації шляхом ії перетворення або пристосування до неї задля мінімізації негативних впливів на особистість, збереження позитивної «Я-концепції», забезпечення психологічного благополуччя особистості [7].

Вивчення особливостей подолання студентами-першокурсниками екзаменаційного стресу ґрунтувалося на таких твердженнях: по-перше, психічний стан $€$ відносно стійкою характеристикою психічної діяльності, характеризуючи ії динаміку та перебіг, і зале- жить від всебічної оцінки ситуації суб'єктом та минулого емоційного досвіду індивіда [3]; по-друге, психічний стан, зокрема екзаменаційний стрес, є складним багаторівневим утворенням, що включає психічний рівень (зокрема, переживання), фізіологічний (центральна нервова система, вегетативна система) та поведінковий рівень (психоемоційні реакції, міміка, пантоміміка) [2] або ж поєднує різні рівні регулювання (моторний, вегетативний, психічний, соціально-психологічний, психологічний, психофізіологічний та фізіологічний) [4]; по-третє, індивідуальні відмінності подолання стресових ситуацій виявляються у особистих, соціальних ресурсах, які використовуються особистістю [7].

Постановка завдання. Мета нашого дослідження полягає у виявленні особливостей подолання екзаменаційного стресу студентами з різним рівнем особистісної тривожності та екзаменаційної тривожності.

Виклад основного матеріалу дослідження. Задля реалізації мети нами було організоване емпіричне дослідження на вибірці, що утворювалася випадковим способом і складалася з 72 студентів перших курсів напрямів підготовки «Педагогічна освіта» денної форми навчання. Вік студентів 17-18 років.

Нами використовувалися такі методи психодіагностичного обстеження: 16-ти факторний особистісний опитувальник Кеттелла (форма С) [1] для вивчення емоційно-вольових рис особистості та рівня тривожності студентів; експрес-тест «Діагностика екзаменаційної тривожності» [5], що дозволив оцінити як загальний рівень екзаменаційної тривожності, так і окремо рівні двох її компонентів: емоційність та занепокоєння; «Методика оцінки психічної активації, інтересу, емоційного тонусу, напруження та комфортності» [5], яка використовувалася для самооцінки студентами основних критеріїв психічного стану в умовах іспиту і передбачала кількісну оцінку психічної активації, інтересу, емоційного тонусу, напруження та комфортності; розроблена нами анкета «Фізіологічні та психологічні ознаки екзаменаційного хвилювання та способи впливу на нього» була спрямована на визначення способів впливу на екзаменаційний стрес задля його зменшення або усунення й оцінки ї ефективності, а також виокремлення симптомів, що виникають у ситуації екзамену. Для визначення статистичної значущості отриманих емпіричним шляхом даних 
використовувався критерій кутового перетворення Фішера $\varphi^{\star}$ та U-критерій Манна-Уїтні.

Психологічні механізми виникнення та динаміки психічних станів, їх зумовленість емоційно-вольовими характеристиками особистості, усвідомлення іх прояву студентами, особливості ситуації, в якій перебувають студенти під час екзаменаційної сесії, визначали не лише вибір діагностичного інструментарію для психологічне обстеження, але й зумовили послідовність пред'явлення методик та вибір термінів збору емпіричних даних. Емпіричне дослідження здійснювалося під час екзаменаційної сесії в університеті. Нами з'ясовувалися емоційно-вольові характеристики та тривожність студентів, безпосередньо перед іспитом визначалися загальний рівень екзаменаційної тривожності студентів, як специфічної форми ситуативної тривожності, здійснювалася оцінка їх актуального стану (психічна активація, інтерес, емоційний тонус, напруження та комфортність) та виявлявся спектр фізіологічних та психологічних ознак екзаменаційного хвилювання та способів впливу на нього.

Вивчення особистісних рис студентів здійснювалося за допомогою 16-ти факторного особистісного опитувальника Р. Кеттелла. Відповідно до мети та теоретичного підґрунтя нашого дослідження піддавалися аналізу фактори C, O, I, $\mathrm{Q}_{3}, \mathrm{Q}_{4}$, що утворюють блок емоційно-вольових рис особистості, а також розраховувався додатковий фактор тривожності $\left(\mathrm{F}_{2}\right)$. Окрім того, за допомогою експрес-тесту «Діагностика екзаменаційної тривожності» вивчалася екзаменаційнатривожністьякодназ форм тривожності, що включає два компоненти: емоційність (неприємні відчуття і фізіологічні реакції, які виникають в результаті стресу) та занепокоєння (думки про наслідки провалу).

Аналіз 5 первинних факторів, що утворюють блок емоційно-вольових рис особистості, та одного вторинного фактору (Фактору тривожності), який отримано за допомогою 16-ти факторного особистісного опитувальника Р. Кеттелла, дозволив виділити чотири групи респондентів, які різнять за емоційно-вольовими характеристиками особистості та рівнем тривожності (див. табл. 1).

Група А з діапазоном значень вторинного фактору $F_{2} 1,3 \ldots 3,99$ вирізняється такими емоційними характеристиками, як емоційна стійкість, впевненість в своїх силах, спокійне адекватне сприймання дійсності, уміння контролювати свої емоції та поведінку, стресостійкість; часто виявляється ригідність.

Група В охоплюе студентів 3 діапазоном значень вторинного фактору $\mathrm{F}_{2} 4 \ldots$ 5,99, що характеризуються емоційною стабільністю, достатнім рівнем контролю своїх емоцій та поведінки, емоційною стабільністю, достатньою стресостійкістю, а також орієнтованістю на соціальний успіх, гнучкістю в судженнях, добре розвинутою уявою.

Респонденти, віднесені нами до групи C 3 діапазоном значень вторинного фактору $\mathrm{F}_{2} 6 \ldots 7,99$, схильні до внутрішнього незадоволення собою, певної тривожності та помисливості, що спричиняють фрустрованість та низьку стресостійкість. Відповідно, представників цієї групи вирізняє емоційна нестабільність, підвищена тривожність, що поєднуються з широкою емоційною палітрою.

Нарешті, у групу D увійшли студенти з діапазоном значень вторинного фактору $\mathrm{F}_{2}$ більше 8; їх вирізняє емоційна нестійкість, підвищена тривожність, невпевненість в собі, низька стресостійкість, надмірна емоційна напруженість, фрустрованість, низький контроль емоцій і поведінки, імпульсивність, афективність.

Аналіз емоційно-вольових рис особистості, що описуються факторами C, O, I, $\mathrm{Q}_{3}, \mathrm{Q}_{4}$, та вторинним фактором $F_{2}$ тесту $P$. Кеттелла виявив такі тенденції у кожній з виділених нами груп: а) за факторами О «спокій - тривожність» та $Q_{4}$ «розслаблення - напруженість» у студентів групи А виявлено негативні значення, а за фактором $\mathrm{Q}_{3}$ «низький самоконтроль-високий самоконтроль» і С «емоційна стабільність емоційна нестабільність»-позитивнізначення, що характеризує цю групу як впевнених в своїх

Таблиця 1

\section{Оцінка первинних та вторинного факторів за Кеттеллом у студентів} з різними рівнями тривожності

\begin{tabular}{|c|c|c|c|c|c|c|c|c|c|c|}
\hline \multirow{2}{*}{ 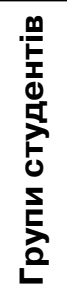 } & \multicolumn{2}{|c|}{$\begin{array}{c}\text { Значення вторинного } \\
\text { Фактору } \mathrm{F}_{2} \text { тесту } \\
\text { Р. Кеттелла «низька } \\
\text { тривожність - висока } \\
\text { тривожність" } \\
\end{array}$} & \multicolumn{5}{|c|}{$\begin{array}{c}\text { Діапазон значень } \\
\text { первинних факторів тесту } \\
\text { Р. Кеттелла (в стенах) }\end{array}$} & \multicolumn{3}{|c|}{$\begin{array}{c}\text { Рівні екзаменаційної } \\
\text { тривожності (\%) }\end{array}$} \\
\hline & $\begin{array}{c}\text { Діапазон } \\
\text { значень } \mathrm{F}_{2}\end{array}$ & $\begin{array}{c}\text { Кількість } \\
\text { випадків } \\
\text { (у \%) }\end{array}$ & C & 0 & I & $\mathbf{Q}_{3}$ & $\mathbf{Q}_{4}$ & Низький & Середній & Високий \\
\hline$A$ & $1,3 \ldots 3,99$ & 20,8 & 8 & 3 & 5 & 7 & 3 & 19,4 & 1,4 & - \\
\hline B & $4 \ldots 5,99$ & 19,4 & 5 & 8 & 4 & 7 & 3 & 9,7 & 9,7 & $\begin{array}{lll}- & & \\
-1\end{array}$ \\
\hline $\mathrm{C}$ & $6 \ldots 7,99$ & 52,8 & 3 & 9 & 5 & 7 & 5 & 5,5 & 22,3 & 25 \\
\hline $\mathrm{D}$ & 8 і більше & 7 & 3 & 10 & 8 & 4 & 7 & 2,8 & 4,2 & - \\
\hline
\end{tabular}


здібностях та в собі, нечутливих до загроз, небоязких, холоднокровних та розсудливих, емоційно стійких та врівноважених і водночас наділених умінням контролювати свої емоції та поведінку, інколи безпечних та самовпевнених, що поєднується 3 в'ялістю, апатичністю, орієнтованих на реальність та працездатних, з низькою мотивацією, що призводить до задоволення невисокими результатами навчання; б) у всіх студентів групи В виявлено позитивні значення за фактором $\mathrm{O}$ «спокій - тривожність» та $Q_{3}$ «низький самоконтроль-високий самоконтроль», і негативні значення за факторами $\mathrm{Q}_{4}$ «розслабленість напруженість» та I «жорсткість - чутливість», що $€$ свідченням того, що респонденти цієї групи характеризуються тривожністю в складних ситуаціях, стурбованістю, невпевненістю в собі, схильністю до погано настрою, очікуванням погано, чутливістю до схвалення оточуючих, а також вимогливістю до себе, наполегливістю, відповідальністю та розвинутим почуттям обов'язку, здатністю контролювати власні емоції, і водночас їм притаманні надмірна задоволеність та незворушність, низька мотивація, реалістичність, незалежність, прагнення покладатися на себе та потреби у розумінні сенсу діяльності; в) за факторами $\mathrm{O}$ «спокій - тривожність» та $\mathrm{Q}_{3}$ «низький самоконтроль - високий самоконтроль» у студентів групи С виявлено позитивні значення, а за фактором C «емоційна стабільність - емоційна нестабільність» негативні значення, такі дані свідчать про те, що емоційна нестійкість, імпульсивність, висока втомлюваність та роздратовуваність поєднуються з тенденцією до тривожності у складних ситуаціях, неспокоєм, ранимістю, невпевненістю в собі, схильністю до передчуттів, чутливістю до схвалення оточуючими; г) у респондендів групи D всі фактори мають позитивне або негативне знання, тобто за факторами О «спокій - тривожність», $\mathrm{Q}_{4}$ «розслаблення - напруженість» та I «жорсткість - чутливість» - позитивні значення, а за факторами $\mathrm{Q}_{3}$ «низький самоконтроль-високий самоконтроль» і C «емоційна стабільність -емоційна нестабільність» негативні значення, що свідчить про тенденцію до тривожності у складних ситуаціях, уникання вимог дійсності, стурбованості, вразливості, їм притаманні страх, невпевненість у собі, схильність до депресій, похмурих передчуттів, напруженість та фрустрованість, підвищена мотивація, рефлексія, невміння контролювати свої емоції та поведінку, фрустрованість, стомлюваність.

Діагностика рівня екзаменаційної тривожності під час іспитів виявила, що у 62,6 \% респондентів високий і середній, у третини першокурсників - низький рівень екзаменаційної тривожності. Як бачимо з таблиці 1, у респондентів групи А загалом переважає низький рівень екзаменаційної тривожності, тоді ж як у студентів груп B і D - низький або середній рівень екзаменаційної тривожності, тоді як у студентів групи С виявлено всі три рівні екзаменаційної тривожності з переважанням високого та середнього рівня (див. табл. 1). Цікаво, що у студентів з низьким рівнем занепокоєння і низьким або середнім рівнем емоційності (в цьому випадку рівень загальної екзаменаційної тривожності середній) значення фактору $F_{2}$ перебуває в діапазоні від 1,3 до 5,99 (тобто це студенти груп А і B), тоді як при значеннях цього фактору, що перевищують 8 одиниць (у респондентів групи D), рівень занепокоєння має мінімальне значення, тоді як рівень емоційності високий або середній рівень.

у 26,3\% респондентів з низьким та високим рівнем екзаменаційної тривожності обидва компоненти екзаменаційної тривожності (емоційність та занепокоєння) були рівними за значенням, тобто тривога за провал на іспиті та сила неприємних відчуттів і фізіологічних проявів, які викликає іспит, були для студентів рівновеликими, що може свідчити про низький рівня домагань студентів. У студенти з середній рівнем екзаменаційної тривожності $(37,6 \%)$ рівні занепокоєння і емоційність суттєво відрізняються, при цьому рівень занепокоєння, як правило, був низького рівня, тоді як емоційний компонент - середнього рівня. Це є свідченням того, що якщо рівень занепокоєння низький, то, як правило, очікування позитивного результату вищі, що й може спричиняти зниження або навпаки суттєве зростання рівня емоційного компоненту екзаменаційної тривожності.

у 5,6\% студентів рівень занепокоєння результатами провалу на іспиті суттєво перевищував рівень їх емоційності, при цьому серед них немає студентів з високим рівнем екзаменаційної тривожності. Можна припустити, що це пов'язано зі значними недоліками в підготовці студентів до іспиту або ж високим рівнем соціального очікування позитивних результатів іспиту оточенням першокурсника.

Водночас у $68,1 \%$ респондентів всіх трьох рівнів загального рівня екзаменаційної тривожності рівень емоційності, тобто фіксації негативних фізіологічних реакцій та неприємних відчуттів, що породжується іспитами, значно вищий, аніж тривога за негативний результат іспиту. Такі значення рівня занепокоєння як компоненту екзаменаційної тривожності є свідченням того, що студенти схильні більше концентруватися на власних неприємних відчуттях та фізіологічних проявах хвилювання, аніж на соціальній значимості іспиту.

У всіх студентів з високим рівнем екзаменаційної тривожності за фактором $\mathrm{F}_{2}$ «низька тривожність - висока тривожність» позитивні значення (більше 7), що свідчить про високий рівень тривоги, яка може бути викликана ситу- 
ацією, в якій здійснюється діяльність (в нашому випадку - це іспит), незадоволення, викликане неможливістю досягнути бажане. У більшості студентів з низьким загальним рівнем екзаменаційної тривожності, і у всіх студентів $з$ низьким рівнем емоційного компоненту екзаменаційної тривожності виявлено негативні значення за фактором $F_{2}$ «низька тривожність - висока тривожність", що свідчать про задоволеність досягнутими результатами діяльності, брак мотивації в складних, напружених ситуаціях. Респонденти, у яких виявлено середній рівень екзаменаційної тривожності за фактором $\mathrm{F}_{2}$ «низька тривожність - висока тривожність» зафіксовані позитивні, негативні значення, що наштовхує на думку, про те, що емоційно-вольові характеристики студентів та ситуація іспиту є основними чинниками, які призводять до таких відмінностей в отриманих результатів. Варто також відзначити, що респонденти, у яких за фактором $F_{2}$ виявлено значення вищі 8, вживають медикаментозні препарати для нормалізації психоемоційного стану впродовж сесії.

Нами виявлено суттєві розбіжності у оцінках окремих критеріїв 16-ти факторного особистісного опитувальника Р. Кеттелла у студентів виділених нами груп за рівнем загальної екзаменаційної тривожності. Встановлено такі статистично значущі відмінності: між групами з високим та низьким рівнем екзаменаційної тривожності у прояві фактора $\mathrm{O}^{-}:\left(\varphi^{*}=3,056\right)$ (для $(p \leq 0,01)$, фактора $Q_{4}^{-*}\left(\varphi^{*}=3,056\right)$ (для $(p \leq 0,01)$; фактор $\mathrm{O}^{+}:\left(\varphi^{\star}=2,764\right)$ (для $(p \leq 0,01)$, та між групами з високим та середнім рівнем екзаменаційної тривожності у прояві фактора I': $\left(\varphi^{*}=3,165\right)$ (для $(p \leq 0,01)$. Встановлені відмінності у прояві факторів у групах респондентів з різним рівнем екзаменаційної тривожності є статистично значущими. Це означає, що саме ці фактори і відповідні їм особистісні риси визначають специфіку психоемоційного стану студентів в ситуації екзамену. Отже, як бачимо, на екзаменаційне хвилювання впливають емоційна оцінка ситуації випробування, рівень особистісної тривожності та емоційновольові характеристики особистості.

Результати самооцінки студентами актуального стану за критеріями психічної активації, інтересу, емоційного тонусу, напруження та комфортності в ситуації іспиту загалом зумовлені емоційно-вольовими характеристиками особистості. Наприклад, впевнені в своїх здібностях та в собі, нечутливі до загроз, холоднокровні та розсудливі, емоційно стійкі таврівноважені, знизькоюмотивацією, щопризводить до задоволення невисокими результатами навчання, орієнтованих на реальність респонденти групи А мають високий рівень інтересу, високий або середній емоційний тонус, середні рівні комфортності та психічної активації. Водночас емоційно нестійкі, імпульсивні, з високою втомлюваністю та роздратовуваністю, тривожністю у складних ситуаціях, невпевненістю в собі, схильністю до передчуттів, чутливістю до схвалення оточуючими студенти групи В мають низьку або середню психічну активацію, емоційний тонус та комфортність, а інтерес і напруженість - високого та середнього рівня.

Емоційно-вольові характеристики особистості визначають також і ставлення першокурсників до ситуації іспиту або як соціально значущої або як загрозливої події, відповідно це породжує різні рівні напруження. Всі студентів з низьким рівнем тривожності (групи А, В) оцінили власний стан як стан високого емоційного тонусу, тобто ситуація іспиту змушує їх до понаднормової психічної активації для досягнення бажаного для них результату та викликає значний інтерес, що породжує середній та високий рівень комфортності. У респондентів груп C і D з високим рівнем тривожності спостерігається частіше низький рівень комфортності, висока напруженість та низька психічна активація через дезорганізуючий вплив ситуації іспиту, як загрозливої для особистості, і значну чутливість до соціальних оцінок.

Нами виявлено відмінності у самооцінці студентами актуального психоемоційного стану за критеріями «психічна активація», «інтерес», «емоційний тонус», «напруженість», комфортність». Використовуючи U-критерій Манна-Уїтні нами встановлено статистично значущі відмінності за оцінкою «психічної активації» між групами респондентів A і B: $\mathrm{U}_{\text {емп }}=33,5$ (для $(\mathrm{p} \leq 0,01)$; між групами респондентів A і C: $U_{\text {емп }}=80$ (для $(p \leq 0,01)$ та між групами респондентів A i D: $U_{\text {емп }}=11$ (для $\mathrm{p} \leq 0,01$ ); за оцінкою «емоційного тонусу» між групами респондентів А і C: $U_{\text {емп }}=120$ (для $p \leq 0,01$ ), за оцінкою «напруженості» між групами B i $A: U_{\text {eмп }}=38$ (для $p \leq 0,01$ ); між групами $\mathrm{B}$ i C: $U_{\text {емп }}=78,5$ (для $p \leq 0,01$ ), між групами B i D: $U_{\text {емп }}=10$ (для $p \leq 0,01$ ), а також між групами B i C за оцінкою «комфортності» $U_{\text {емп }}=148$ (для $\mathrm{p} \leq 0,01)$. Отримані результати засвідчують, що відмінності у самооцінці власного психічного стану за критеріями психічної активації, напруженості, комфортності та емоційного тонусу у студентів з різним рівнем тривожності $€$ статистично значущою.

Респонденти висловили 582 судження про способи подолання екзаменаційного хвилювання та 482 судження про основні засоби подолання екзаменаційного хвилювання, які ними використовуються. Варто відзначити, що представники групи С здатні виокремити майже вдвічі більшу кількість суджень про способи подолання і більш критично ставлять до ефективності способів подолання екзаменаційного стресу, виокремлюючи ситуації, в яких 
спосіб діє, та його ефективність (у відсотках), тоді як у студентів груп A, B i D менший арсенал способів подолання екзаменаційного стресу і зафіксовано лише дві полярні оцінки «діє/не діє» пропонований спосіб подолання екзаменаційного стресу. При цьому спостерігається незначне переважання кількості висловлювань про способи подолання емоційного стресу у респондентів групи $A$, а у респондентів групи C - незначно переважає кількість висловлювань про симптоми екзаменаційного стресу.

Для подолання екзаменаційного стресу студентами використовуються або конструктивні способи, які забезпечують зниження напруження i, водночас, забезпечують достатню продуктивність діяльності в ситуації іспиту, або деструктивні способи подолання екзаменаційного стресу, які усувають зовнішні прояви екзаменаційного хвилювання і не забезпечують достатньої продуктивності в ситуації іспиту або завдають шкоди здоров'ю студентів. Співвідношення конструктивних та деструктивних способів подолання екзаменаційного стресу у студентів всіх чотирьох груп практично однакове і складає 3:1. Студенти першого курсу найчастіше вдаються до таких способів подолання екзаменаційного стресу: вплив на фізичний стан організму з метою зниження хвилювання (92 судження); відволікання від ситуації іспиту, "випадіння з ситуації» (63 судження) і спілкування як психотерапевтичний засіб (68 суджень). Спостерігаються окремі відмінності у виборі конструктивних і деструктивних способів подолання екзаменаційного стресу студентами кожної з груп. Так, студенти групи A, B, C і D для зниження хвилювання використовують: вплив на фізичний стан організму з метою зниження хвилювання (фізичні вправи, рухова активність; дихальні вправи; вживання певної їжі; водні процедури тощо), спілкування 3 рідними, батьками, друзями для отримання вербальної підтримки. Респонденти групи С окрім описаних вище способів вдаються досить часто до практики самонавіювання, використання уяви для подолання хвилювання. Студенти групи D загалом обмежуються лише трьома групами способів подолання екзаменаційного хвилювання, один з яких є деструктивним («вихід) випадіння» $з$ ситуації іспиту). Респонденти груп A і D не використовують лікарські препарати для подолання екзаменаційного стресу, а студенти груп А і В не вдаються до духовних практик (читання мантр, молитви тощо). У групах В і С досить популярними способами подолання екзаменаційного стресу виявилися прикмети та екзаменаційні забобони.

Значущі розбіжності за частотою вибору способів подолання екзаменаційного стресу під час іспиту респондентами з різними рівнями тривожності (як риси особистості та стану) виявлено для таких конструктивних способів «вплив на фізичний стан організму 3 метою зниження хвилювання» $\left(\varphi^{*}=2,611\right)$ (для $(p \leq 0,01)$ між групами респондентів B та D та «самонавіювання» $\left(\varphi^{\star}=5,006\right)$ (для $(p \leq 0,01)$ між групами респондентів A і C)та $\left(\varphi^{\star}=2,813\right)$ (для $(p \leq 0,01)$ між групами респондентів C i D, a також значущі відмінності виявлено для деструктивного способу «вживання лікарських препаратів для зниження хвилювання» $\left(\varphi^{\star}=2,726\right)$ (для $(p \leq 0,01)$ між групами респондентів А і В та $\left(\varphi^{\star}=3,192\right)$ для $(p \leq 0,01)$ між групами респондентів А і С. Встановлені відмінності засвідчують, що вибір способу подолання екзаменаційного стресу студентами з різними рівнями тривожності є статистично суттєвим. Решта відмінностей не $є$ статистично значущою або визначити її неможливо з огляду на відсутність вибору деяких способів, що розглядалися у респондентів кожної з виділених нами груп. Встановлені відмінності підтверджують вплив на вибір способу подолання екзаменаційного хвилювання особливостей емоційно-вольових якостями особистості студентів та рівня тривожності.

Висновки з проведеного дослідження. Особливості подолання екзаменаційного стресу зумовлюються емоційно-вольовими особливостями особистості та, відповідно, рівнем тривожності особистості. Провідними особистісними рисами респондентів з низьким рівнем екзаменаційної тривожності $є$ впевненість у собі і своїх здібностям, яка інколи переходить у самовпевненість, врівноваженість, незворушність, розсудливість, нечутливість до загроз, що поєднується з апатією, в'ялістю та низькою мотивацією, лінню. У студентів з високим рівнем екзаменаційної тривожності зафіксовано такі особистісні риси невпевненість у собі та своїх силах, схильність до поганого настрою, очікування неуспіху, песимізму, що переплітається з наполегливістю, відповідальністю, почуттям обов'язку, вимогливістю до себе. Студенти, які виявили середній рівень екзаменаційної тривожності водночас з помірною вимогливістю до себе, відповідальністю, прагматичністю та не зворушливістю виявляють більшу агресивність та брак або слабку мотивацію, що призводить до невисоких результатів навчання та діяльності.

Оскільки ситуація іспиту є складною життєвою ситуацією, то здатна викликати зміни психоемоційного стану першокурсника. Психоемоційний стан студентів з середнім та низьким рівнем екзаменаційної тривожності відрізняється від психоемоційного стану студентів з високим рівнем екзаменаційної тривожності. Зокрема, в ситуації іспиту перші переживають виснаження, втому, прагнення спокою, соматичний дискомфорт, емоційну нестійкість, потребу в соціальній активності, 
спілкуванні, ригідність, оптимістичність, тоді як стан студентів з високим рівнем екзаменаційної тривожності вирізняється дратівливістю, агресивністю захисного характеру, ірраціональними способами захисту від стресу, прагненням домінувати, наявністю високої мотивації досягнень. Загалом, для студентів з середніми показниками особистісної тривожності стан напруження та стресу виявився тонізуючим, таким, що дозволяе зберігати достатній рівень працездатність та боротися за хороший результат навчання.

Нами також доведено, що відмінності за критеріями психічної активації, напруженості, комфортності та емоційного тонусу у студентів з різним рівнем тривожності є статистично значущими. Так, у студентів групи А з низьким рівнем тривожності психічна активація в ситуації екзаменаційного стресу нижча порівняно зі студентами інших трьох груп (B, C i D), а напруженість у студентів групи В з помірним рівнем тривожності значно нижча, ніж у студентів з інших трьох груп (A, C і D), i, нарешті, емоційний тонус та комфортність студентів групи С з високим рівнем тривожності значно вищий у ситуації іспиту, ніж у студентів з групи Аз низьким рівнем тривожності і В з помірним рівнем тривожності. Такі відмінності зумовлені також емоційно-вольовими властивостями кожної з груп респондентів за рівнем тривожності.

У ситуації іспиту студентами використовуються різноманітні способи зниження рівня стресу. Отримані результати емпіричного дослідження виявили, що загалом виробилася система сталих когнітивних, поведінкових довільних способів подолання екзаменаційного стресу. Виявлено значущі розбіжності за частотою вибору способів подолання екзаменаційного стресу респондентами з різними рівнями тривожності. Нами встановлено, що студенти з високим рівнем тривожності оці- нюють ситуацію іспиту як загрозливу і це змушує їх вибирати не лише ширший діапазоном конструктивних, але й деструктивні способи подолання екзаменаційного хвилювання.

3 огляду на отримані нами результати перспективним ми вважаємо розробку програми психологічного супроводу адаптації першокурсників 3 метою формування копінг-поведінки у стресових ситуаціях, зокрема до ситуацій пов'язаних з різноманітними випробовуваннями.

\section{ЛІТЕРАТУРА:}

1. Выбойшик И.В., Шакурова З.А. Личностный многофракторный опросник Р. Кэттелла : учеб. пособие. Челябинск : Изд.ЮУрГУ, 2000. 54 с.

2. Ильин Е.П. Эмоции и чувства. Санкт-Петербург : Питер, 2001, 752 с.

3. Кондаш О. Хвилювання: страх перед випробовуванням. Київ : Радянська школа. 1981. 170 с.

4. Максименко К.С. Переживання і подолання особистісно негативних психічних станів при хронічних соматичних захворюваннях : авторес. дис. на здобуття наук. ступеня к. психол. наук: 19.00.04. Київ, 2010. $18 \mathrm{c}$.

5. Практикум по психологии состояний: учебн. пособие / под ред. проф. А. О. Прохорова. СанктПетербург: Речь, 2004. 480 с.

6. Степаненко Л.В. Емоційні властивості в системі саморегуляції психологів. Габітус. 2020. Вип. 20. C. 56-61.

7. Стресс, выгорание, совладание в современном контексте / под ред. А.Л. Журавлева, Е.А. Сергиенко. Москва: Ин-т психологии РАН, 2011. 512 с.

8. Щербатых Ю.В. Вегетативные проявления экзаменационного стресса : автореф. дис. на соиск. науч. степени д-ра биол. наук : 03.00.13, 19.00.02. Санкт-Петербург, 2001. 32 с.

9. Lasarus R.S., Launier R. Stress - related transactions between person and environment. L.A. Pervin, M.Lewis Perspectives in iteractional psychology. N.Y.: Plenum, 1978. P. 287-327. 